Jurnal Akuntansi AKTIVA, Vol 1, No 2, Oktober 2020

\title{
REAKSI PASAR MODAL TERHADAP KEMENANGAN IR. H. JOKO WIDODO PADA PEMILIHAN PRESIDEN DI INDONESIA TAHUN 2019 ( Studi Pada Saham LQ 45 Tahun 2019)
}

\author{
${ }^{1}$ Resalia Indrianti, ${ }^{2}$ Suyanto, ${ }^{3}$ Sri Retnaning Rahayu \\ 1,2,3Fakultas Ekonomi dan Bisnis Universitas Muhammadiyah Metro, Lampung \\ 1esaliaindrianti17@gmail.com
}

\begin{abstract}
This research is an event study research that aims to find out how big the reaction of the Indonesian capital market is to the victory of the Joko Widodo pair in the 2019 Presidential Election with the indicators used in the form of abnormal returns and trading volume activity on the LQ45 index stock group. This study uses secondary data in the form of daily data. stock prices, daily data on LQ45 index, daily data on trading volume, and daily data on the volume of shares outstanding during the period of seven days before, one day during, and seven days after the event. The day of the event was May 22, 2019. Sampling used a purposive sampling method. The type of data used is quantitative data. The data collection technique in this research is by means of documentation. Testing the hypothesis using the One-Sample $t$ Test and Paired Sample t-Test. The results showed that there were significant differences in the reaction between the average before and after the event. However, there is no significant difference between the average abnormal returns before the event. Similar to the average abnormal return after the event, there is a significant difference in the average trading volume before and after the event. There is a significant difference in the average trading volume before and during the event. There is a significant difference in the average trading volume after and during the event.
\end{abstract}

Key words: Jokowi, Event study, abnormal return, trading volume activity, LQ45, Pilpres 2019.

\begin{abstract}
ABSTRAK
Penelitian ini merupakan penelitian event study yang bertujuan untuk mengetahui seberapa besar reaksi pasar modal Indonesia terhadap peristiwa kemenangan pasangan Joko Widodo pada Pilpres 2019 dengan indikator yang digunakan berupa abnormal return dan trading volume activity pada kelompok saham indeks LQ45.Penelitian ini menggunakan data sekunder berupa data harian harga saham, data harian indeks LQ45, data harian volume perdagangan, dan data harian volume saham yang beredar selama periode tujuh hari sebelum, satu hari saat, dan tujuh hari setelah peristiwa. Hari saat peristiwa yaitu pada tanggal 22 mei 2019. Penggambilan sampel menggunakan teknik pusposive sampling method. Jenis data yang digunakan adalah data kuantitatif. Teknik pengambilan data dalam penelitian ini dengan cara dokumentasi. Pengujian terhadap hipotesis menggunakan One-Sample t Test dan Paired Sample t-Test. Hasil penelitian menunjukkan terdapat perbedaan reaksi yang signifikan atas rata-rata sebelum dengan setelah peristiwa. Namun tidak ada perbedaan signifikan antara rata-rata abnormal return sebelum dengan saat peristiwa. Sama halnya dengan rata-rata abnormal return setelah dengan saat peristiwa.Terdapat perbedaan signifikan rata-rata trading volume activity sebelum dan setelah peristiwa. Terdapat perbedaan signifikan rata-rata trading volume activity sebelum dan saat peristiwa. Terdapat perbedaan signifikan rata-rata trading volume activity setelah dan saat peristiwa.
\end{abstract}

Kata Kunci: Jokowi, Event study, abnormal return, trading volume activity, LQ45, Pilpres 2019. 


\section{PENDAHULUAN}

Pasar modal merupakan pasar untuk berbagai instrumen keuangan (atau sekuritas) jangka panjang yang bisa diperjualbelikan, baik dalam bentuk utang, maupun modal sendiri, baik yang diterbitkan oleh pemerintah, public authorities, maupun perusahaan swasta (Suad Husnan 2015:3). Selain sebagai wadah dari berbagai instrumen keuangan, Sudirman (2015:12) menyatakan bahwa pasar modal dapat juga berfungsi sebagai lembaga perantara (intermediaries). Fungsi menunjukkan peran penting pasar modal dalam menunjang perekonomian karena pasar modal dapat menghubungkan pihak yang membutuhkan dana dengan pihak yang mempunyai kelebihan dana. Di samping itu, pasar modal dapat mendorong terciptanya alokasi dana yang efisien, karena pihak investor dapat memilih alternatif investasi yang memberikan return yang paling optimal.

Pengalokasian dana berupa investasi sejatinya bertujuan mendapatkan return yang besar dengan alternatif tertentu di masa yang akan datang. Tandelilin E (2010:105), return saham merupakan salah satu faktor yang memotivasi investor berinvestasi dan juga merupakan imbalan atas keberanian investor menanggung risiko atas investasi yang dilakukannya. Sudah dapat dipastikan bahwa return atau keuntungan yang diharapkan oleh investor merupakan return yang sebesar - besarnya. Namun perlu diperhatikan bahwa return yang besar memiliki kemungkinan risiko yang besar, dikarenakan perusahaan atau emiten yang memiliki return yang tinggi biasanya merupakan saham "blue chip" atau perusahaan yang memiliki nilai pasar tinggi dan pergerakan usaha yang besar. Selain dari pergerakan usaha, nilai pasar suatu saham juga dipengaruhi oleh berbagai faktor yang menimbulkan perbedaan return antar investor, emiten dan jenis kegiatan usahanya.

Stabilitas politik suatu negara sangatlah penting, selain sebagai pendongkrak perekonomian regional juga perekonomial internasional terlebih bagi negara berkembang seperti Indonesia. Hal tersebut dikarenakan setiap negara berkembang akan saling berlomba mendapatkan investor internasional untuk mendapatkan kemajuan yang diidamkan (Dr. Mohamad Samsul 2015:42). Tentunya memang ada beberapa bentuk tolak ukur kestabilan politik suatu negara. Salah satu contoh dari peristiwa tersebut yaitu pemilihan umum atau lebih sering disebut dengan "Pemilu”. Seperti yang telah kita ketahui pada bulan April 2019 Indonesia telah melakukan pemilihan umum Lembaga legislatif yaitu Anggota Dewan Perwakilan Rakyat (DPR), Anggota Dewan Perwakilan Daerah (DPD), serta anggota Dewan Perwakilan Rakyat Daerah (DPRD Provinsi maupun DPRD Kabupaten/Kota) se-Indonesia periode 2019-2024 dan dilaksanakan bersamaan dengan Pemilihan umum Presiden Indonesia 2019. Atas pemilu tersebut pada tanggal 21 Mei 2019 ditetapkan bawa Presiden terpilih Indonesia Periode 2019-2024 yaitu Ir. H. Joko Widodo. Pro dan kontra yang terjadi atas pengumuman tersebut bukan merupakan menjadi hal yang ditunggu oleh seluruh masyarakat Indonesia saja, tetapi juga oleh investor asing. 
Hal tersebut dikarenakan kebijakan dan stabilitas politik yang terjadi merupakan arah mata angin dari sebagian investor yang tujuan investasinya jangka panjang. Ketika stabilitas ataupun keputusan politik dianggap merupakan hal positif maka para pelaku pasar modal tersebut akan mendapatkan return yang positif juga. Sebaliknya, jika hal tersebut dianggap negatif maka return yang didapat biasanya lebih kecil dari pada yang diharapkan. Return yang didapat pada saat kondisi tersebut biasanya disebut dengan Abnormal return.

Penelitian Dame perwira dan I.B Panji Sedana (2018) tentang Reaksi Pasar Modal Indonesia Terhadap Kemenangan Donald Trump Pada Pilpres 2016 di Amerika Serikat didapatkan abnormal return positif tertinggi pada $\mathrm{t}+6$ dan terendah pada $\mathrm{t}+3$. Hal tersebut menunjukkan bahwa pergerakan saham LQ45 sekalipun memiliki kesensitifan dengan peristiwa-peristiwa yang ada disekitarnya hal tersebut sejalan dengan pernyataan jika pasar bereaksi dengan cepat dan akurat terhadap suatu informasi yang masuk dan segera membentuk harga keseimbangan yang baru, maka kondisi pasar yang seperti ini yang disebut dengan pasar efisien (Jogiyanto, 2013:547).

Selain Abnormal Return pergerakan atau reaksi pasar modal dapat dilihat dari kenaikan tingkat volume transaksi / Trading Volume Activity (TVA). TVA biasanya menunjukkan keadaan atau kondisi pasar sedang mengalami bearish/bullish. Pada penelitian Dame perwira dan I.B Panji Sedana (2018) tentang Reaksi Pasar Modal Indonesia Terhadap Kemenangan Donald Trump Pada Pilpres 2016 di Amerika Serikat didapatkan nilai TVA tertinggi pada $\mathrm{t}+1$ yang bersamaan dengan menurunnya tingkat abnormal return menandakan pada saat tersebut keadaan pasar sedang mengalami bearish. Hasil penelitian tersebut hampir sama dngan hasil dari penelitiandari Aryo Pamungkas dkk (2015) yang meneliti tentang pemilihan pilpres 2012 terhadap abnormal return dan trading volume activity. Dari hasil penelitiannya, dinyatakan bahwa TVA tertinggi juga terjadi saat $\mathrm{t}+1$ dengan hasil abnormal return yang juga berada pada rata rata negatif. Hal tersebut juga terjadi pada pemilihan umum tahun 2019 dengan data yang diperoleh dari Yahoo Finance sebagai berikut:

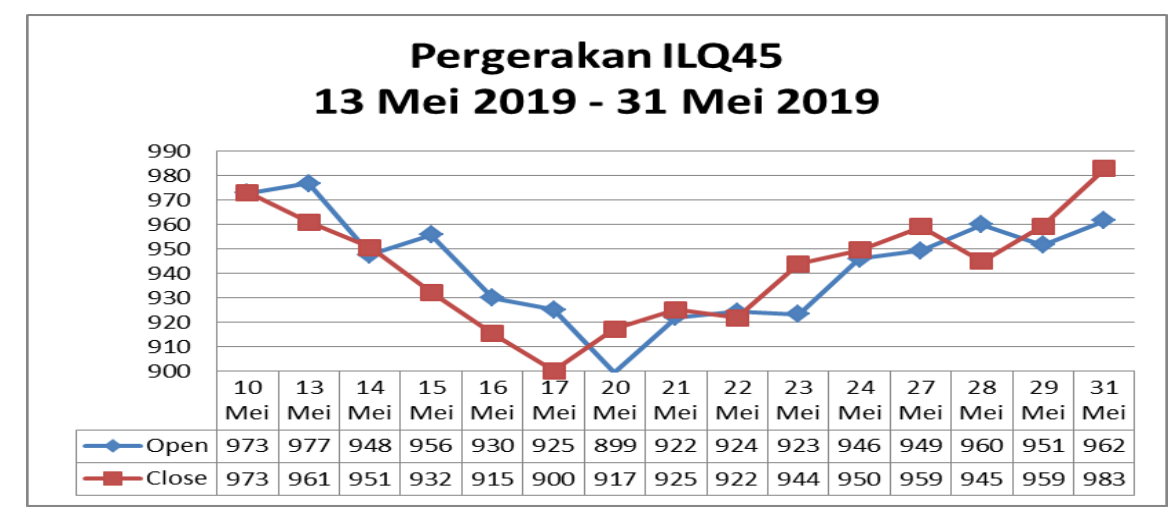

Gambar 1. Pergerakan saham yang masuk dalam ILQ-45 selama Periode Pengamatan(Sumber : www.finance.yahoo.com) 


\section{LANDASAN TEORI}

\section{Deskripsi Teori}

Studi peristiwa (event study) merupakan studi yang mempelajari reaksi pasar terhadap suatu peristiwa (event) yang informasinya dipublikasikan sebagai suatu pengumuman. Reaksi pasar dalam hal ini adalah abnormal return dan trading volume activity. Studi peristiwa dapat digunakan untuk menguji kandungan informasi dari suat pengumuman yang dapat digunakan untuk mengukur tingkat efisiensi pasar bentuk setengah kuat (Jogiyanto, 2017:643). Efisiensi dari suatu pasar dapat terlihat dari kecepatan reaksi atas pengumuman yang mengandung informasi telah disampaikan.

Pada penelitian kali ini hal yang menjadi titik focus penelitian merupakan kejadian pengumuman kemenangan Ir. H. Joko Widodo pada Pilpres 2020 yang sangat merubah bentuk dari pergerakan saham khususnya pada Indeks LQ45. Berikut merupakan pengertian dari pasar modal

1. Eduardus Tandelilin (2010:26)

Pengertian pasar modal menurut Eduardus Tandelilin adalah pertemuan antara pihak yang memiliki kelebihan dana dengan pihak yang membutuhkan dana dengan cara memperjualbelikan sekuritas, sedangkan tempat di mana terjadinya jual beli sekuritas disebut dengan bursa efek.

2. Widoatmojo (2012:15)

Pasar modal adalah pasar abstrak, di mana yang diperjualbelikan adalah dana-dana jangka panjang, yaitu dana yang berkaitannya dalam investasi lebih dari satu tahun.

Produk pasar modal yang menjadi obyek penelitian ini yaitu saham. Dimana saham merupakan asset dan sumber pendapatan tidak tetap yang pergerkannya secara cepat dan terus menerus setiap hari dan jam aktif bursa. Berikut merupakan pengertian dari saham:

1. Undang-undang No.8 tahun 1995

Saham/efek adalah surat berharga, yaitu surat pengakuan utang, surat berharga komersil, obligasi, tanda bukti utang, dan unit penyertaan kontrak investasi kolektif.

2. Mohamad Samsul (2015:59)

Saham adalah tanda bukti kepemilikan perusahaan.

Saham Memiliki bentuk reaksi pasar yang bermacam-macam yang disebabkan oleh berbagai faktor. Dalam hal ini diambil dua buah bentuk reaksi pasar yang mewakili bentuk reaksi pasar atas event yang terjadi pada bulan mei 2019 ini yaitu Abnormal return dan Trading Volume activity. 


\section{Abnormal Return}

Dalam pasar efisien, harga sekuritas seharusnya merefleksikan informasi mengenai risiko dan harapan mengenai return masa depannya. Return yang sepadan dengan risiko saham disebut return normal. Sedangkan jika pasar adalah tidak efisien, sekuritas akan menghasilkan return yang lebih besar dibanding normalnya, yang disebut abnormal return (Tandelilin: 2010:223).

Sementara Jogiyanto (2017:556) menyebutkan bahwa jika digunakan abnormal return, maka dapat dikatakan bahwa suatu pengumuman yang memiliki kandungan informasi akan memberikan abnormal return kepada pasar. Sebaliknya yang tidak mengandung informasi tidak memberikan abnormal return kepada pasar. Abnormal return menurut Jogiyanto (2017:667) adalah selisih antara tingkat keuntungan sebenarnya (actual return) dengan tingkat keuntungan yang diharapkan (expected return). Abnormal return atau excess return ini merupakan kelebihan dari return yang sesungguhnya terjadi terhadap return normal. Return normal merupakan return yang diharapkan oleh investor dengan mempertimbangkan tingkat risikonya.

\section{Aktivitas Volume Perdagangan (Trading Volume Activity)}

Aktivitas volume perdagangan (Trading Volume Activity /TVA) merupakan salah saatu instrumen yang menunjukkan reaksi pasar modal terhadap informasi melalui pergerakan aktivitas volume perdagangan di pasar modal. Ditinjau dari fungsinya, maka dapat dikatakan bahwa TVA merupakan suatu variasi dari event study. Aktivitas volume perdagangan atau Trading Volume Activity (TVA) merupakan suatu penjumlahan volume dari setiap transaksi perdagangan yang terjadi di bursa saham pada waktu dan saham tertentu. Menurut Zamroni (dalam Hamidi: 2008), volume perdagangan merupakan unsur kunci dalam melakukan prediksi terhadap pergerakan harga saham.

Suryawijaya dan Setiawan dalam Indarti (2003:17) menyebutkan bahwa pendekatan TVA dapat pula digunakan untuk menguji hipotesis efisiensi pasar bentuk lemah (weak-form efficiency). Karena pada pasar yang belum efisien, perubahan harga belum secara cepat mencerminkan informasi yang ada, sehingga para peneliti terdahulu hanya dapat mengamati reaksi pasar modal melalui pergerakan volume perdagangan. Perubahan volume perdagangan menurut Crouch dan Winsen serta Ro dalam Indarti (2003: 19) dapat timbul tanpa adanya perubahan harga apabila kelebihan permintaan seorang pedagang ditutup oleh kelebihan penawaran pedagang lainnya tanpa mengarah pada suatu ekuilibrium baru. Berbeda dengan Sugianto (dalam Hamidi, 2008: 36) yang menyatakan bahwa naik turunnya volume perdagangan dapat dianggap sebagai indikator trend harga yang berubah-ubah atau dikenal dengan metode volume reversal. 


\section{Kerangka Pemikiran}

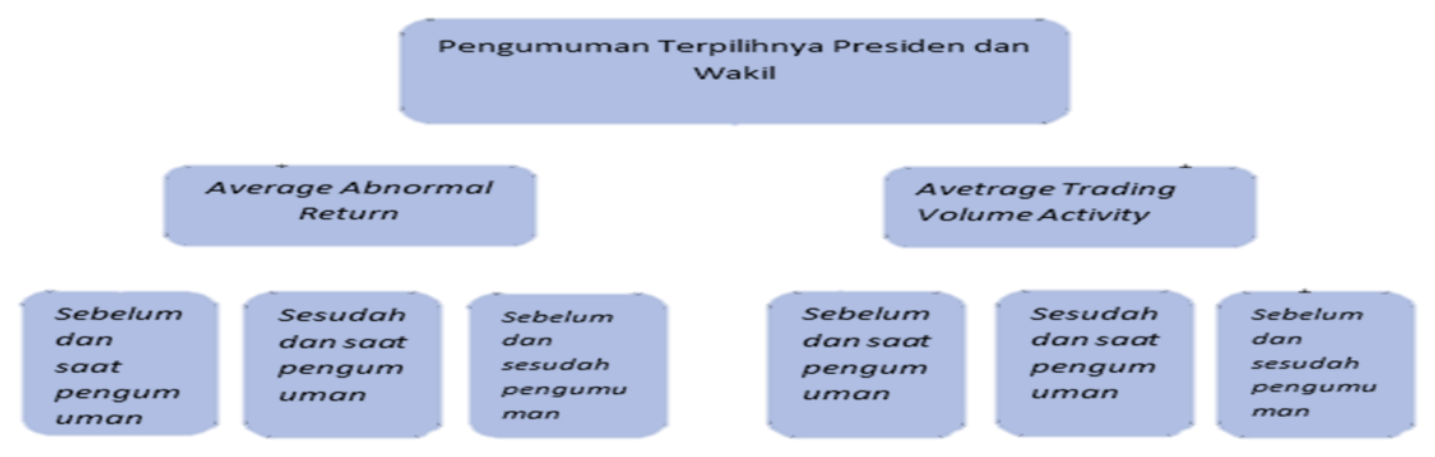

GAMBAR 3. Kerangka Pemikiran

\section{Hipotesis Penelitian}

Berdasarkan teori dan latar belakang permasalahan yang dikemukakan sebelumnya, maka dapat dibuat beberapa hipotesis terhadap permasalahan sebagai berikut:

$\mathrm{H} 1$ = Terdapat perubahan rata-rata abnormal return antara sebelum dan setelah pengumuman kemenangan Ir. H. Joko widodo sebagai Presiden Indonesia 2019

$\mathrm{H} 2$ = Terdapat perubahan rata-rata abnormal return antara sebelum dan saat pengumuman kemenangan Ir. H. Joko widodo sebagai Presiden Indonesia 2019

$\mathrm{H} 3$ = Terdapat perubahan rata-rata abnormal return antara setelah dan saat pengumuman kemenangan Ir. H. Joko widodo sebagai Presiden Indonesia 2019

H4 = Terdapat perubahan rata-rata trading volume activity antara sebelum dan setelah pengumuman kemenangan Ir. H. Joko widodo sebagai Presiden Indonesia 2019

$\mathrm{H} 5$ = Terdapat perubahan rata-rata trading volume activity antara sebelum dan saat pengumuman kemenangan Ir. H. Joko widodo sebagai Presiden Indonesia 2019

H6 = Terdapat perubahan rata-rata trading volume activity antara setelah dan saat pengumuman kemenangan Ir. H. Joko widodo sebagai Presiden Indonesia 2019

\section{METODE PENELITIAN}

Penelitian ini merupakan penelitian dengan pendekatan studi peristiwa, di mana fokus utamanya adalah mempelajari reaksi pasar modal terhadap informasi yang diumumkan secara terbuka. Menurut Jogiyanto,(2017:644) jika pengumuman mengandung informasi (information content), maka diharapkan pasar akan bereaksi pada waktu pengumuman tersebut diterima oleh pasar. Bentuk dari reaksi pasarnya dapat berupa perubahan harga yang dapat dikur dengan abnormal return. oleh sebab itu, pada pengumuman kemenangan Joko widodo sebagai Presiden Indonesia dalam pemilihan umum 2019 akan dinyatakan mengandung informasi jika menimbulkan reaksi pasar. Yang artinya abnormal return diterima, sebaliknya jika tidak mengandung informasi maka dinyatakan tidak ada abnormal return yang diterima. 
Dalam penelitian ini data yang digunakan merupakan data dari situs resmi Bursa Efek Indonesia. Populasi dalam penelitian ini merupakan perusahaan-perusahaan yang termasuk dalam kelompok indeks saham LQ45 pada periode Februari - Juli 2019. Penentuan sampel dilakukan dengan metode purpovise judgement sampling yaitu penentuan secara tidak acak (non probabilitas) yang informasinya diperoleh dengan menggunakan pertimbangan tertentu. Sampel data yang diambil adalah emiten yang masuk dalam kelompok indeks LQ45 dengan kriteria sebagai berikut:

a. Tidak melakukan corporate action diwaktu periode pengamatan, dengan tujuan untuk menghindari confounding effect yang disebabkan oleh aksi korporasi perusahaan. Corporate action ini meliputi stock spilt, merger, right issue, pengumuman dividen, saham bonus, dan lain-lain.

b. Tetap termasuk dalam kelompok LQ45 pada periode sebelumnya (Agustus - Januari 2019) atau secara 2 periode berturut - turut masuk dalam indeks LQ45. Periode pengamatan penelitian berada pada 10-31 Mei 2019. Sementara pergantian data chart LQ45 yaitu setiap enam bulan sekali yaitu pada awal Februari dan awal Agustus.

Teknik analisis data yang digunakan dalam penelitian ini adalah analisis statistik deskriptif, Uji asumsi klasik (uji normalitas dan uji linieritas), dan Uji Hipotesis (one sample t-test dan paired sample t-test).

\section{HASIL PENELITIAN DAN PEMBAHASAN}

\section{Hasil Penelitian}

Berdasarkan ketentuan atas pengambilan sample dari 45 data perusahaan yang termasuk dalam indeks LQ45 yang lolos dari kriterisa sample hanya 28 Perusahaan. Yang berarti terdapat 28 data yang dijadikan sample pada penelitian kali ini

Berdasarkan data hasil olahan tersebut maka akan dilakukan pengujian untuk mengetahui hasil penelitian. Pengujian yang akan dilakukan yaitu statistik deskriptif data tersebut, uji normalitas data, dan uji statistik (one sample t-test dan paired sample t-test).

\section{Statistik Deskriptif}

Staistik deskriptif adalah statistik yang digunakan untuk menganalisis data dengan cara mendeskripsikan atau menggambarkan data yang telah terkumpul sebagaimana adanya tanpa bermaksud membuat kesimpulan yang berlaku untuk umum atau generalisasi. Data yang akan dilihat meliputi ratarata (mean), standar deviasi, nilai maksimal, nilai minimal, dan jumlah data penelitian. 
Tabel 1. Statistik Deskriptif

\begin{tabular}{lccccc}
\hline \multicolumn{6}{c}{ Descriptive Statistics } \\
\hline N & \multicolumn{1}{c}{ Minimum } & Maximum & Mean & $\begin{array}{c}\text { Std. } \\
\text { Deviation }\end{array}$ \\
\hline Return Saham & 15 & $-0,0257733$ & 0,0266193 & 0,0018156 & 0,0178566 \\
Return Pasar & 15 & $-0,0194163$ & 0,0245377 & 0,0008747 & 0,0157304 \\
Abnormal Rerturn & 15 & $-0,01327183$ & 0,01305358 & 0,00094090 & 0,00711664 \\
Trading Volume Activity & 15 & 0,00116356 & 0,00266831 & 0,00188061 & 0,00041402 \\
Valid N (listwise) & 15 & & & & \\
\hline
\end{tabular}

Sumber : Hasil olah data dengan SPSS 25

Berdasarkan Tabel 1. Statistik Deskriptif diatas dapat diketahui hasil secara jelas dari setiap variabel dalam penelitian ini.

\section{Analisis Data}

Analisis data dalam penelitian ini dengan menormalisasi data menggunakan Kolmogorov-Smirnov Test. Kriteria yang dipergunakan adalah pengujian dua sisi (two tailed Test) yakni membandingkan sig yang diperoleh dengan taraf signifikansi sebesar 5\%. Apabila sig. > 0,05 maka data tersebut telah berdistribusi normal dan sebaliknya jika sig. $<0,05$ maka data tersebut tidak berdistribusi normal. Alat uji beda yang akan digunakan tergantung dari hasil uji normalitas data. Parametic Test: paired sample t Test digunakan apabila data berdistribusi normal namun jika data tidak berdistribusi normal maka menggunakan non-parametric Test : Wilcoxon Signed Rank Test. Berikut ini merupakan hasil uji normalitas :

a. Analisis Data Average Abnormal Return

\begin{tabular}{|c|c|c|c|}
\hline \multicolumn{4}{|c|}{ One-Sample Kolmogorov-Smirnov Test } \\
\hline & & Sebelum & Setelah \\
\hline \multicolumn{2}{|l|}{$N$} & 7 & 7 \\
\hline \multirow[t]{2}{*}{ Normal Parameters $s^{a, b}$} & Mean & -.00082959 & .00153855 \\
\hline & Std. Deviation & .007492138 & .006836350 \\
\hline \multirow[t]{3}{*}{ Most Extreme Differences } & Absolute & .271 & .218 \\
\hline & Positive & .175 & .218 \\
\hline & Negative & -.271 & -.151 \\
\hline \multicolumn{2}{|l|}{ Test Statistic } & .271 & .218 \\
\hline \multicolumn{2}{|l|}{ Asymp. Sig. (2-tailed) } & $.131^{c}$ & $.200^{c, d}$ \\
\hline \multicolumn{4}{|c|}{ a. Test distribution is Normal. } \\
\hline \multicolumn{4}{|l|}{ b. Calculated from data. } \\
\hline \multicolumn{4}{|c|}{ c. Lilliefors Significance Correction. } \\
\hline \multicolumn{4}{|c|}{$d$. This is a lower bound of the true significance. } \\
\hline
\end{tabular}

Sumber : hasil output SPSS 25 
Dari data di atas dapat dilihat bahwa penyebaran data average abnormal return setelah dan sebelum pengumuman dengan uji Kolmogorov-Smirnov ${ }^{a}$. Yang menunjukkan hasil berdistribusi secara normal dengan nilai sig lebih besar dari 0,05. Pada AAR sebelum pengumuman didapat sig senilai 0,131 dan pada AAR setelah pengumuman jumlah sig yaitu 0,200.

\section{b. Analisis Data Average Trading Volume Activity}

\begin{tabular}{|l|l|r|r|}
\hline \multicolumn{3}{|c|}{ One-Sample Kolmogorov-Smirnov Test } \\
\hline \multirow{2}{*}{$N$} & tvabefore & Tvaafter \\
\hline \multirow{2}{*}{ Normal Parameters ${ }^{a, b}$} & Mean & 7 & 7 \\
\cline { 2 - 4 } & Std. Deviation & .00194271 & .00177031 \\
\hline \multirow{2}{*}{ Most Extreme Differences } & Absolute & .000312015 & .000514746 \\
\cline { 2 - 4 } & Positive & .252 & .140 \\
\cline { 2 - 4 } & Negative &. .135 & .140 \\
\hline Test Statistic & & .252 & $.200^{c, d}$ \\
\hline Asymp. Sig. (2-tailed) & $.200^{c, d}$ & \\
\hline a. Test distribution is Normal. & & \\
\hline b. Calculated from data. & & \\
\hline c. Lilliefors Significance Correction. & & \\
\hline d. This is a lower bound of the true significance. & & \\
\hline
\end{tabular}

Sumber : hasil output SPSS 25

Dari data di atas dapat dilihat bahwa penyebaran data average trading volume activity setelah dan sebelum pengumuman dengan uji Kolmogorov-Smirnov ${ }^{a}$. Yang menunjukkan hasil berdistribusi secara normal dengan nilai sig lebih besar dari 0,05. Pada ATVA sebelum dan setelah pengumuman didapat sig senilai 0,200

c. Paired sample t-test

\begin{tabular}{|c|c|c|c|c|c|c|c|c|c|}
\hline \multicolumn{10}{|c|}{ Paired Samples Test } \\
\hline & & \multicolumn{5}{|c|}{ Paired Differences } & \multirow{3}{*}{$\mathrm{t}$} & \multirow{3}{*}{ df } & \multirow{3}{*}{$\begin{array}{l}\text { Sig. (2- } \\
\text { tailed) }\end{array}$} \\
\hline & & \multirow[t]{2}{*}{ Mean } & \multirow[t]{2}{*}{$\begin{array}{l}\text { Std. } \\
\text { Deviation }\end{array}$} & \multirow[t]{2}{*}{$\begin{array}{ll}\text { Std. } & \text { Error } \\
\text { Mean } & \end{array}$} & $\begin{array}{l}95 \% \\
\text { Interval } \\
\text { Differen }\end{array}$ & $\begin{array}{l}\text { Confidence } \\
\text { of the }\end{array}$ & & & \\
\hline & & & & & Lower & Upper & & & \\
\hline Pair 1 & $\begin{array}{l}\text { Aar before - } \\
\text { aarafter }\end{array}$ & -.00236 & .01313 & .00496 & -.01451 & .00978 & -.477 & 6 & .650 \\
\hline
\end{tabular}

Sumber : hasil output SPSS 25

Dari data di atas dapat disimpulkan bahwa nilai asymp. Sig (2-tailed) bernilai $>0,05$ pada average abnormal return saham sebelum dan setelah pengumuman presiden terpilih di Indonesia yaitu sebesar 
0,0650 yang membuktikan terdapat perbedaan yang signifikan pada average abnormal return saham, dengan demikian hipotesis kesatu (H1) dalam penelitian ini diterima dan menolak $\mathrm{H}_{0}$.

\begin{tabular}{|c|c|c|c|c|c|c|c|c|c|}
\hline \multicolumn{10}{|c|}{ Paired Samples Test } \\
\hline & & \multicolumn{5}{|c|}{ Paired Differences } & \multirow[t]{3}{*}{$\mathrm{T}$} & \multirow[t]{3}{*}{ df } & \multirow{3}{*}{$\begin{array}{l}\text { Sig. (2- } \\
\text { tailed) }\end{array}$} \\
\hline & & \multirow[t]{2}{*}{ Mean } & \multirow[t]{2}{*}{$\begin{array}{l}\text { Std. } \\
\text { Deviation }\end{array}$} & \multirow[t]{2}{*}{$\begin{array}{ll}\text { Std. } & \text { Error } \\
\text { Mean } & \end{array}$} & \multicolumn{2}{|c|}{$\begin{array}{l}\text { 95\% Confidence Interval of the } \\
\text { Difference }\end{array}$} & & & \\
\hline & & & & & Lower & Upper & & & \\
\hline $\begin{array}{l}\text { Pair } \\
1\end{array}$ & $\begin{array}{l}\text { Tvabefore- } \\
\text { tvaafter }\end{array}$ & .0001723 & .000652 & .0002465 & -.0004309 & .0007757 & .699 & 6 & .511 \\
\hline
\end{tabular}

Sumber : hasil output SPSS 25

Dari data di atas dapat disimpulkan bahwa nilai asymp. Sig (2-tailed) bernilai $>0,05$ pada average trading volume activity saham sebelum dan setelah pengumuman presiden terpilih di Indonesia yaitu sebesar 0,511 yang membuktikan terdapat perbedaan yang signifikan pada average trading volume activity saham, dengan demikian hipotesis keempat $(\mathrm{H} 4)$ dalam penelitian ini diterima dan menolak $\mathrm{H}_{0}$.

\section{Uji one sample t-test}

1. average abnormal return sebelum dan saat pengumuman

\begin{tabular}{|c|c|c|c|c|c|c|}
\hline \multicolumn{7}{|c|}{ One-Sample Test } \\
\hline & \multicolumn{6}{|c|}{ Test Value $=.009151$} \\
\hline & \multirow[t]{2}{*}{$\mathrm{T}$} & \multirow[t]{2}{*}{$\mathrm{Df}$} & \multirow[t]{2}{*}{ Sig. (2-tailed) } & \multirow[t]{2}{*}{$\begin{array}{c}\text { Mean } \\
\text { Difference }\end{array}$} & \multicolumn{2}{|c|}{$\begin{array}{c}\text { 95\% Confidence Interval of the } \\
\text { Difference }\end{array}$} \\
\hline & & & & & Lower & Upper \\
\hline Aarbefore & -3.525 & 6 & .012 & -.009980590 & -.01690966 & -.00305152 \\
\hline
\end{tabular}

Sumber : hasil output SPSS 25

Dari data di atas dapat disimpulkan bahwa nilai asymp. Sig (2-tailed) bernilai $<0,05$ pada average abnormal return sebelum dan saat pengumuman presiden terpilih di Indonesia yaitu sebesar 0,012 yang menyatakan bahwa tidak terdapat perbedaan yang signifikan pada average abnormal return sebelum dan saat pengumuman , dengan demikian hipotesis kedua $(\mathrm{H} 2)$ dalam penelitian ini ditolak dan menerima $\mathrm{H}_{0.1}$

\section{Average Abnormal Return setelah dan Saat Pengumuman}

\begin{tabular}{|c|c|c|c|c|c|c|}
\hline \multicolumn{7}{|c|}{ One-Sample Test } \\
\hline & \multicolumn{9}{|c|}{ Test Value $=.009151$} \\
\cline { 2 - 7 } & $\mathrm{T}$ & Df & Sig. (2-tailed) & Mean Difference & \multicolumn{2}{c|}{ 95\% Confidence Interval of the Difference } \\
\cline { 2 - 7 } & & & & & Lower & Upper \\
\hline Aarafter & -2.946 & 6 & .026 & -.007612448 & -.01393502 & -.00128988 \\
\hline
\end{tabular}

Sumber : hasil output SPSS 25 
Dari data di atas dapat disimpulkan bahwa nilai asymp. Sig (2-tailed) bernilai $<0,05$ pada average abnormal return setelah dan saat pengumuman presiden terpilih di Indonesia yaitu sebesar 0,026 yang menyatakan bahwa tidak terdapat perbedaan yang signifikan pada average abnormal return setelah dan saat pengumuman, dengan demikian hipotesis ketiga (H3) dalam penelitian ini ditolak dan menerima $\mathrm{H}_{0}$

\section{Average trading volume activity saham sebelum dan saat pengumuman}

\begin{tabular}{|c|c|c|c|c|c|c|}
\hline \multicolumn{7}{|c|}{ One-Sample Test } \\
\hline & \multicolumn{6}{|c|}{ Test Value $=.002218$} \\
\hline & \multirow[t]{2}{*}{$T$} & \multirow[t]{2}{*}{$D f$} & \multirow[t]{2}{*}{ Sig. (2-tailed) } & \multirow[t]{2}{*}{ Mean Difference } & \multicolumn{2}{|c|}{$\begin{array}{l}\text { 95\% Confidence Interval of the } \\
\text { Difference }\end{array}$} \\
\hline & & & & & Lower & Upper \\
\hline Tvabefore & -2.334 & 6 & .058 & -.000275286 & -.00056385 & .00001328 \\
\hline
\end{tabular}

Sumber : hasil output SPSS 25

Dari data di atas dapat disimpulkan bahwa nilai asymp. Sig (2-tailed) bernilai > 0,05 pada average trading volume activity saham sebelum dan saat pengumuman presiden terpilih di Indonesia yaitu sebesar 0,058 yang membuktikan terdapat perbedaan yang signifikan pada average trading volume activity saham sebelum dan saat pengumuman, dengan demikian hipotesis kelima (H5) dalam penelitian ini diterima dan menolak $\mathrm{H}_{0}$.

\section{Average Trading Volume Activity setelah dan Saat Pengumuman}

\begin{tabular}{|c|c|c|c|c|c|c|}
\hline \multicolumn{7}{|c|}{ One-Sample Test } \\
\hline & \multicolumn{6}{|c|}{ Test Value $=.002218$} \\
\hline & \multirow{2}{*}{$T$} & \multirow{2}{*}{$D f$} & \multirow{2}{*}{ Sig. (2-tailed) } & \multirow{2}{*}{ Mean Difference } & \multicolumn{2}{|c|}{$\begin{array}{l}\text { 95\% Confidence Interval of the } \\
\text { Difference }\end{array}$} \\
\hline & & & & & Lower & Upper \\
\hline Tvaafter & -2.301 & 6 & .061 & -.000447686 & -.00092375 & .00002837 \\
\hline
\end{tabular}

Sumber : hasil output SPSS 25

Dari data di atas dapat disimpulkan bahwa nilai asymp. Sig (2-tailed) bernilai > 0,05 pada average trading volume activity saham setelah dan saat pengumuman presiden terpilih di Indonesia yaitu sebesar 0,061 yang membuktikan terdapat perbedaan yang signifikan pada average trading volume 
activity saham setelah dan saat pengumuman, dengan demikian hipotesis keenam (H6) dalam penelitian ini diterima dan menolak $\mathrm{H}_{0}$.

\section{PEMBAHASAN}

Penelitian ini ditujukan untuk mengetahui reaksi saham terhadap event yaitu reaksi saham yang tergolong indeks LQ45 terhadap pengumuman kemenangan Joko Widodo Pada 21 Mei 2020 Sehingga akan dijelaskan pembahasan dari hasil penelitian pada masing-masing variabel yaitu sebagai berikut:

\section{Average Abnormal Return Saham sebelum dan setelah Pengumuman Kemenangan Jokowi sebagai Presiden Terpilih di Indonesia tahun 2019}

Pada hasil penelitian pada saham sample selama tujuh hari sebelum dan tujuh hari setelah pengumuman kemenangan terhadap 28 perusahaan yang memenuhi kriteria sebagai sampel. Secara keseluruhan dapat diketahui bahwa terdapat perbedaan yang sangat signifikan pada abnormal return saham antara sebelum dan setelah pengumuman kemenangan Jokowi sebagai Presiden terpilih di Indonesia tahun 2019. Hal tersebut merupakan adanya penerimaan informasi yang dipercayai oleh pemegang saham.

Hasil penelitian ini juga sejalan dengan hasil penelitian yang dilakukan oleh Dame Prawira Silaban (2018) dan Ayudia Hanung Diniar (2015), yang menyatakan bahwa terdapat perbedaan rata-rata abnormal return yang signifikan pada periode sebelum dan sesudah pengumuman atas presiden terpilih. Hal tersebut menunjukan bahwa pada peristiwa pengumuman atas presiden terpilih baik di Indonesia maupun Negara lain, yang menyatakan bahwa setelah pengumuman atas presiden terpilih, keadaan abnormal return berubah secara signifikan, yaitu berada pada optimal trading range terjadi. Sehingga dapat dinyatakan bahwa terdapat perbedaan yang signifikan pada AAR saham setelah dan sebelum pengumuman atas presiden terpilih. Hal ini berarti atas presiden terpilih memiliki reaksi yang signifikan terhadap perubahan AAR saham.

\section{Average Abnormal Return Saham sebelum dan saat Pengumuman Kemenangan Jokowi sebagai Presiden Terpilih di Indonesia tahun 2019}

Pada hasil penelitian pada saham sample selama tujuh hari sebelum dan tujuh hari setelah pengumuman kemenangan terhadap 28 perusahaan yang memenuhi kriteria sebagai sampel. Secara keseluruhan dapat diketahui bahwa tidak terdapat perbedaan yang sangat signifikan pada abnormal return saham antara sebelum dan saat pengumuman kemenangan Jokowi sebagai Presiden terpilih di Indonesia tahun 2019. Hasil penelitian ini juga sejalan dengan hasil penelitian yang dilakukan oleh Ni Nengah Sureni Yuniarthi (2016) dan Ayudia Aryo Pamungkas (2015), Penelitian tersebut menyatakan bahwa 
tidak terdapat perbedaan rata-rata abnormal return yang signifikan pada periode pengamatan atas pengumuman presiden terpilih.

Hal tersebut secara langsung menyatakan informasi pada saat tersebut belum diterima dengan baik oleh pemegang saham. Namun merupakan tanda yang baik, dimana ketika abnormal returnnya tidak terlalu besar mengartikan keadaan kegiatan pasar saham berjalan normal dan kondusif. Sehingga dapat dinyatakan bahwa tidak terdapat perbedaan yang signifikan pada AAR saham sebelum dan saat pengumuman atas presiden terpilih. Hal ini berarti atas presiden terpilih tidak memiliki reaksi yang signifikan terhadap perubahan AAR saham.

\section{Average Abnormal Return Saham setelah dan saat Pengumuman Kemenangan Jokowi sebagai Presiden Terpilih di Indonesia tahun 2019 \\ Pada hasil penelitian pada saham sample selama tujuh hari sebelum dan tujuh hari setelah} pengumuman kemenangan terhadap 28 perusahaan yang memenuhi kriteria sebagai sampel. Secara keseluruhan dapat diketahui bahwa tidak terdapat perbedaan yang sangat signifikan pada abnormal return saham antara setelah dan saat pengumuman kemenangan Jokowi sebagai Presiden terpilih di Indonesia tahun 2019. Hasil penelitian ini juga sejalan dengan hasil penelitian yang dilakukan oleh Ni Nengah Sureni Yuniarthi (2016) dan Ayudia Aryo Pamungkas (2015), Penelitian tersebut menyatakan bahwa tidak terdapat perbedaan rata-rata abnormal return yang signifikan pada periode pengamatan atas pengumuman presiden terpilih

Hal tersebut secara langsung menyatakan informasi pada saat tersebut belum diterima dengan baik oleh pemegang saham. Namun merupakan tanda yang baik, dimana ketika abnormal returnnya tidak terlalu besar mengartikan keadaan kegiatan pasar saham berjalan normal dan kondusif. Sehingga dapat dinyatakan bahwa tidak terdapat perbedaan yang signifikan pada AAR saham setelah dan saat pengumuman atas presiden terpilih. Hal ini berarti atas event presiden terpilih tidak memiliki reaksi yang signifikan terhadap perubahan AAR saham.

\section{Average Trading Volume Activity Saham sebelum dan setelah Pengumuman Kemenangan Jokowi sebagai Presiden Terpilih di Indonesia tahun 2019}

Pada hasil penelitian pada saham sample selama tujuh hari sebelum dan tujuh hari setelah pengumuman kemenangan terhadap 28 perusahaan yang memenuhi kriteria sebagai sampel. Secara keseluruhan dapat diketahui bahwa terdapat perbedaan yang sangat signifikan pada trading volume activity saham antara sebelum dan setelah pengumuman kemenangan Jokowi sebagai Presiden terpilih di Indonesia tahun 2019. 
Hasil penelitian ini juga sejalan dengan hasil penelitian yang dilakukan oleh Dame Prawira Silaban (2018) dan Aryo Pamungkas(2015), Penelitian tersebut menyatakan bahwa terdapat perbedaan rata-rata trading volume activity yang signifikan pada periode sebelum dan setelah pengumuman atas presiden terpilih. Hal tersebut menunjukan bahwa pada peristiwa pengumuman atas presiden terpilih baik di Indonesia dapat menjadi acuan keadaan suatu saham maupun pasar saham yang ada di dalamnya. Atas respon yang diberikan oleh pemegang saham, dapat kita nyatakan adanya kemungkinan perkembangan yang baik saat pembelian saham yang menimbulkan kenaikan tingkat ATVA dan harga saham. Sehingga dapat dinyatakan bahwa terdapat perbedaan yang signifikan pada ATVA saham setelah dan sebelum pengumuman atas presiden terpilih. Hal ini berarti pengumuman atas presiden terpilih memiliki reaksi yang signifikan terhadap perubahan ATVA saham yang terjadi.

\section{Average Trading Volume Activity Saham sebelum dan saat Pengumuman Kemenangan Jokowi sebagai Presiden Terpilih di Indonesia tahun 2019 \\ Pada hasil penelitian pada saham sample selama tujuh hari sebelum dan tujuh hari setelah} pengumuman kemenangan terhadap 28 perusahaan yang memenuhi kriteria sebagai sampel. Secara keseluruhan dapat diketahui bahwa terdapat perbedaan yang sangat signifikan pada trading volume activity saham antara sebelum dan saat pengumuman kemenangan Jokowi sebagai Presiden terpilih di Indonesia tahun 2019.

Hasil penelitian ini juga sejalan dengan hasil penelitian yang dilakukan oleh I Made Deva Hasdawi Putra (2018) dan Ayudiya Hanum (2015), Penelitian tersebut menyatakan bahwa terdapat perbedaan rata-rata trading volume activity yang signifikan pada pengamatan ataspengumuman presiden terpilih. Hal tersebut menunjukan bahwa pada peristiwa pengumuman atas presiden terpilih di Indonesia dapat menjadi acuan keadaan suatu saham maupun pasar saham yang ada di dalamnya. Sehingga dapat dinyatakan bahwa terdapat perbedaan yang signifikan pada ATVA saham saat dan sebelum pengumuman atas presiden terpilih. Hal ini berarti pengumuman atas presiden terpilih memiliki reaksi yang signifikan terhadap perubahan ATVA saham yang terjadi.

\section{Average Trading Volume Activity Saham setelah dan saat Pengumuman Kemenangan Jokowi sebagai Presiden Terpilih di Indonesia tahun 2019}

Pada hasil penelitian pada saham sample selama tujuh hari sebelum dan tujuh hari setelah pengumuman kemenangan terhadap 28 perusahaan yang memenuhi kriteria sebagai sampel. Secara keseluruhan dapat diketahui bahwa terdapat perbedaan yang sangat signifikan pada trading volume activity saham antara sebelum dan saat pengumuman kemenangan Jokowi sebagai Presiden terpilih di Indonesia tahun 2019. Hal tersebut merupakan adanya penerimaan informasi yang dipercayai oleh pemegang saham. Informasi yang diterima oleh pemegang saham biasanya berupa signal atas akan 
adanya perkembangan atau penurunan atas pergerakan perusahaan yang disebabkan oleh peristiwa tersebut.

\section{KESIMPULAN}

Berdasarkan pada hasil serta pembahasan penelitian di atas, dari hasil uji statistik deskriptif, uji normalitas menggunakan Kolmogorov-Smirnov Test, analisis hipotesis menggunakan One Sample T-test, dan analisis hipotesis dengan Paired Sample T-Test dapat disimpulkan bahwa hasil dari penelitian dengan periode pengamatan pada 10-31 Mei 2019 sebagai berikut :

1. Pada analisis reaksi abnormal return sebelum dan sesudah pengumuman Presiden terpilih di Indonesia dapat dibuktikan bahwa terdapat perbedaan yang signifikan pada average abnormal return saham, dengan demikian hipotesis kesatu $(\mathrm{H} 1)$ dalam penelitian ini diterima dan menolak $\mathrm{H}_{0}$.

2. Average abnormal return sebelum dan saat pengumuman presiden terpilih di Indonesia dapat dibuktikan bahwa tidak terdapat perbedaan yang signifikan pada average abnormal return sebelum dan saat pengumuman, dengan demikian hipotesis kedua $(\mathrm{H} 2)$ dalam penelitian ini ditolak dan menerima $\mathrm{H} 0$.

3. Average abnormal return setelah dan saat pengumuman presiden terpilih di Indonesia dapat dibuktikan bahwa tidak terdapat perbedaan yang signifikan pada average abnormal return setelah dan saat pengumuman, dengan demikian hipotesis ketiga (H3) dalam penelitian ini ditolak dan menerima H0

4. Pada analisis reaksi average trading volume activity saham sebelum dan setelah pengumuman presiden terpilih di Indonesia dapat dibuktikan bahwa terdapat perbedaan yang signifikan pada average trading volume activity saham, dengan demikian hipotesis keempat (H4) dalam penelitian ini diterima dan menolak $\mathrm{H}_{0}$.

5. Average trading volume activity saham sebelum dan saat pengumuman presiden terpilih di Indonesia dapat dibuktikan bahwa terdapat perbedaan yang signifikan pada average trading volume activity saham sebelum dan saat pengumuman, dengan demikian hipotesis kelima (H5) dalam penelitian ini diterima dan menolak $\mathrm{H} 0$.

6. Average trading volume activity saham setelah dan saat pengumuman presiden terpilih di Indonesia dapat dibuktikan bahwa terdapat perbedaan yang signifikan pada average trading volume activity saham setelah dan saat pengumuman, dengan demikian hipotesis keenam (H6) dalam penelitian ini diterima dan menolak H0. 


\section{DAFTAR LITERATUR}

Brigham, Eugene F. Dan J.F. Houston. 2010. Dasar-Dasar Manajemen Keuangan. Edisi 11. Jakarta: Salemba Empat

Hadi, Nor. 2013. Pasar Modal: Acuan Teoritis dan Praktis Investasi dan Instrumen keuangan Pasar Modal, edisi Pertama. Yogyakarta: Graha Ilmu. P:67

Hartono, Jogiyanto 2015. Studi Peristiwa: Menguji Reaksi Pasar Modal Akibat Suatu Peristiwa. Yogyakarta: BPFE

Hartono, Jogiyanto.2017.Teori Portofolio dan Analisis Investasi. Edisi Kesebelas Yogyakarta; BPFE.

Husnan, Suad.2015. Dasar-dasar Teori Portofolio dan Analisis Sekuritas. Edisi 5, Yogyakarta : BPFE

Juhaya S. Pradja.2012 Lembaga Keuangan Syariah., Suatu Kajian Teoritis Praktis Bandung: CV Pustaka Setia

Kartono. Kartini,1996, Pemimpin dan Kepimpinan.CV.Rajawali : Bandung.

Kasmir, Bank dan Lembaga Keuangan Lainnya, Jakarta : Rajawali Pers,

Madura, Jeff. 2011. International Corporate Finance, buku 2. Jakarta: Salemba empat

Matthee, H. 2011. Analisis risiko politik. Thousand Oaks, CA: SAGE Publications, Inc.

OJK.2015 Buku Saku Otoritas Jasa Keuangan.Edisi ke 2, Jakarta, p:187

Pantzalis, C, Stangeland, DA and Turtle, H, J. 2000. Political Elections and the Resolution of Certainty:

The International Evidence. Journal of Banking anf Finance. 24(10), p:1575-1604.

Samsul, Muhammad.2015, Pasar Modal \& Manajemen Portofolio, Edisi 2. Surabaya:Erlangga

Sudirman, 2015. Pasar Modal dan Manajemen Portofolio, editor Rizal Darwis,

Sugiyono. 2013. Metode Penelitian Pendidikan Kuantitatif, Kualitatif, dan R\&D.Bandung:Alfabeta.

Sunariyah. 2011. Pengantar Pengetahuan Pasar Modal. Yogyakarta: UPP AMP YKPN,

Tandellin, E. 2010, Anlisis Investasi dan Mnajemen Fortofolio Edisi pertama Cetakan pertama. BPFE Yogyakarta.

Widoatmodjo, Sawidji. 2012. Cara Sehat Investasi di Pasar Modal. Edisi Revisi. Jakarta: PT. Jurnalindo Aksara Grafika.

Chusna, Fitria "hasil pilpres 2019 jokowi-Ma'ruf”, mei 2019

https://nasional.kompas.com/read/2019/05/21/02440251/hasil-pilpres-2019-jokowi-Ma'ruf-5550-persenprabowo-sandi-4450-persen. Penulis Fitria Chusna Farisa | Editor Krisiandi

IDX Indonesia, www.idx.co.id. Diakses pada September-2019

Yahoo Finance,www.idx.com. Diakses pada Desember-2019 
Deva, Made.2018. Analisis Reaksi Pasar Sebelum dan Setelah Pengumuman Kemenangan Donald Trump Menjadi Presiden Amerika Serikat

Dwi, adelia. 2015. Reaksi Pasar Modal Indonesia Terhadap Peristiwa Politik Dalam Negeri: Pemilu Presiden 09 Juli 2014. Surakarta: universitas surakarta

Hanung, Ayudia. 2015. Analisis Dampak Pemilu Presiden Jokowi Terhadap Return Saham (Studi Kasus Saham LQ-45 di Bursa Efek Indonesia) Jurnal Akuntansi Indonesia, Vol. 4 No. 2 Juli 2015, Hal. 97- 108

Handayani,Nofi, Analisis Pengaruh Informasi Laporan Arus Kas Terhadap Volume Perdagangan Saham Perusahaan Yang Tergabung Dalam Jakarta Islamic Index, Skripsi, Fakultas Syariah Institut Agama Islam Negeri Walisongo, Semarang, 2009, hlm. 20

Pamungkas, Aryo. 2015. Pengaruh Pemilu Presiden Indonesia tahun 2014 terhadap Abnormal Return dan Trading Volume Activity (Studi Pada Perusahaan Yang Tercatat Sebagai Anggota Indeks Kompas100)Perwira, Dame. 2018. Reaksi Pasar Modal Indonesia Terhadap Kemenangan Donald Trump pada Pilpres 2016 di Amerika Serikat.

Prabandari, Merida. 2015. Dampak Pengumuman Kemenangan Jokowi Pada Pemilihan Umum Presiden 2014 Terhadap Abnormal Return Saham LQ 45 Di Bursa Efek Indonesia. Yogyakarta :UNY

Sureni, nengah. 2016. Reaksi Pasar Modal Terhadap Pencalonan Jokowi Menjadi Presiden Republik Indonesia

Wardani, Siti. 2018. Pengaruh Peristiwa Politik (Pemilu Presiden dan Pengumuman Susunan Kabinet) Terhadap Saham Sektor Industri Di Bursa Efek Indonesia. Capital, Volume 1, Nomor 2, Maret 2018

Republik Indonesia. 1995. Undang-Undang No. 8 Tahun 1995 tentang Pasar Modal. Lembaran Negara RI Tahun 1995, No. 22 Sekretariat Negara. Jakarta. 